\title{
Association of Ghrelin and Resistin With Body Fat Composition and Insulin Resistance in Chronic Renal Failure
}

\author{
Samar Marzouk*, Amal El-Shehaby*, Amr Zahra*, \\ Mohamed El-Khatib**, Naglaa Mostafa***, and Soha Talaat*** \\ Departments of Medical Biochemistry*, Internal Medicine**, and \\ Radiology*** Faculty of Medicine, Cairo University
}

\begin{abstract}
The metabolic role of the energy modulating hormone ghrelin and the adipocytokine resistin is perturbed in uremia and could contribute to nutritional abnormalities. Malnutrition is an important risk factor for mortality in uremic patients. The present study aimed to clarify the possible role of ghrelin and resistin in malnutrition observed in patients with chronic renal failure and to study their interrelationship, as well as, their correlation with body fat composition and insulin resistance. The study was performed on sixty patients and twenty control subjects matched for age, sex, and body mass index (BMI). The patients were classified into two groups: 30 patients with end-stage renal failure on chronic hemodialysis; and 30 pre-dialysis chronic renal failure patients on conservative treatment. All patients and control subjects were subjected to a thorough clinical assessment, and estimation of fasting plasma levels of lipid profile, creatinine, glucose, insulin, ghrelin and resistin. Insulin resistance was assessed using the homeostatic assessment model for insulin resistance (HOMA $\mathrm{IR}_{\mathrm{R}}$ ). Body fat composition was measured in all subjects by means of dual-energy $X$ - ray absorptiometry (DEXA). Plasma ghrelin and resistin levels were significantly higher in both hemodialysis and pre-dialysis groups compared to control subjects. Furthermore, plasma ghrelin and resistin levels were significantly higher in hemodialysis group compared to pre-dialysis group. In hemodialysis group, a significant negative correlation was found between plasma ghrelin and each of resistin, $B M I$, insulin, $H O M A_{I R}$, and truncal fat mass, while a significant positive correlation between plasma ghrelin and creatinine was found. In pre-dialysis group, plasma ghrelin was inversely correlated significantly with BMI, insulin, $H O M A_{I R}$, and truncal fat mass, but positively correlated significantly with creatinine and lean body mass. As regards plasma resistin, no correlation was found between resistin and any of the studied parameters in that group. In control subjects, plasma ghrelin showed significant negative correlation with BMI, and both truncal fat mass and body fat mass, but a significant positive correlation was detected between plasma ghrelin and lean body mass. However, plasma resistin was negatively correlated significantly with truncal fat mass, body fat mass, and positively correlated significantly with lean body mass. Multiple regression analysis showed that plasma ghrelin was dependent on BMI in both hemodialysis and predialysis subjects and on truncal fat mass in control subjects.
\end{abstract}


In conclusion, plasma ghrelin and resistin concentration were markedly elevated in patients with end-stage renal failure, which might be caused by decreased metabolism or excretion in renal failure. The negative correlation between plasma ghrelin and fat composition and insulin suggest that anorexia causes increase in ghrelin secretion in dialysis patients, which might be a compensatory mechanism rather than a causative factor. However, the lack of association between the increased plasma resistin and fat composition and insulin resistance suggest that resistin is not likely a mediator of nutritional status and insulin resistance in patients with end-stage renal failure.

Key words: ghrelin, resistin, insulin resistance, end-stage renal failure.

\section{INTRODUCTION}

End-stage kidney failure is a chronic condition associated with a high prevalence of nutritional dysfunction ${ }^{(\mathbf{1})}$. Malnutrition is resistant to intervention and is a major predictor of morbidity and mortality in patients who receive hemodialysis $^{(2)}$. There is a linear correlation between body mass index (BMI) and survival in dialysis patients, to the extent that the usual association of increased mortality with obesity is reversed in patients who receive renal replacement therapy ${ }^{(3)}$.

Understanding of the physiology of energy metabolism and appetite regulation has much progressed with the recent discovery of a number of important metabolic hormones, including ghrelin and resistin $(4,5)$. Ghrelin is an endogenous orexigenic 28-amino-acid peptide recently identified in the stomach as an endogenous ligand for the growth hormone (GH) secretagogue receptor ${ }^{(6)}$. Also, other tissues synthesize ghrelin, including the kidney ${ }^{(7)}$. Ghrelin is involved in shortterm regulation of food intake since its plasma levels increase before meals and decrease strongly postprandially. Ghrelin is, also, involved in long-term body-weight regulation by inducing $\operatorname{adiposity}^{(\mathbf{8 , 9}, 10)}$. In general, loss of body fat mass and wasting due to cancer $^{(\mathbf{1 1 )}}$, cardiac cachexia ${ }^{(\mathbf{1 2})}$ or anorexia nervosa ${ }^{(13)}$ is associated with elevated circulating levels of ghrelin. Ghrelin levels seem to be downregulated in human obesity, and negative correlations between ghrelin and both serum leptin and plasma insulin have been reported ${ }^{(14)}$.

Resistin, another recently discovered adipose-specific secreted hormone, is also a potent regulator of glucose homeostasis that is thought to oppose the action of insulin in peripheral tissues ${ }^{(5)}$. Circulating resistin levels tend to increase in obesity and resistin appears to impair glucose tolerance ${ }^{(15)}$. Patients with renal diseases are characterized by resistance to the action of insulin, which is accompanied by hyperinsulinemia and glucose intolerance ${ }^{(16)}$. Previous studies have documented that insulin resistance is present very early in the course of renal disease ${ }^{(\mathbf{1 7}, 18)}$. However, it is not known, whether resistin is associated with the pathogenesis of anorexia and cachexia in patients with end-stage renal disease.

The present study aimed to clarify the possible role of ghrelin and resistin in malnutrition observed in patients with chronic renal failure and 
to study their interrelationship, as well as, their correlation with body fat composition and insulin resistance.

\section{SUBJECTS \& METHODS}

The present study was conducted on 60 patients with renal failure and 20 healthy subjects; they were divided into three groups as follows:

Group I $(\mathbf{n = 3 0 ) :}$ non-diabetic patients with end stage renal failure (ESRF) on chronic haemodialysis, 15 females and 15 males (age range 25 to 67 years).

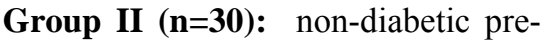
dialysis patients with chronic renal failure (CRF) on conservative treatment, 14 females and 16 males (age range 24 to 68 years)

Group III $(\mathbf{n}=\mathbf{2 0})$ : healthy control subjects matched for age, sex and body mass index (BMI), 10 females and 10 males (age range 23 to 64 years).

The causes of renal failure among hemodialysis patients varied between chronic glomerulonephritis (15\%), hypertensive nephrosclerosis $(46.4 \%)$, polycystic kidney disease $(5 \%)$, and unknown causes $(26.6 \%)$. All the patients had required regular hemodialysis for 3-4 hours a day three times a week for mean hemodialysis duration of $102 \pm 56$ months (range 24 to 480 months); they were receiving unfractionated heparin as an anticoagulant during their hemodialysis sessions.

All the patients were recruited from the Dialysis Unit and Outpatients' Clinic in Kasr Al-Aini Hospital, Cairo University. All participants gave their informed consent before participation in the study. All patients were clinically stable; their body weight was stable for 6 months prior to enrolment with no sign of clinically overt malnutrition. They were all free of acute illness and no clinical or laboratory signs of infection were observed (white blood cells within normal range, $\mathrm{CRP}<0.1 \mathrm{mg} / \mathrm{dl}$ ), without administration of oral contraceptives in women of childbearing age, and normal liver function tests. None of the patients was receiving steroids, anticoagulants or cytotoxic drugs.

Forty patients had arterial hypertension and were receiving antihypertensive medication. Antihypertensive medications that are known to confound the assessment of insulin sensitivity ( $\beta$-blockers, diuretics) were replaced by other medications one week prior to blood withdrawal. Treatment with vitamin D and/or recombinant human erythropoietin were discontinued at least two weeks before blood withdrawal.

Detailed history taking and physical examination were done to exclude the presence of cardiac, hepatic, renal, gastrointestinal or malignant disease which might affect the parameters to be investigated. Body mass index (BMI) was calculated by weight in $\mathrm{kg} /$ height in $\mathrm{m}^{2(\mathbf{1 9})}$ for all subjects.

Analytic procedures: Following an overnight fast (12 hours), venous blood samples was collected. In hemodialysis patients, blood was withdrawn in the morning before the onset of the first dialysis session of the week (before heparin administration). The following 
laboratory investigations were performed for each subject:

1- Estimation of plasma

\begin{tabular}{llr}
\hline creatinine $^{(20)}$, & glucose & $\mathbf{( 2 1 )}$ \\
\hline triglycerides & (22), & total
\end{tabular}

cholesterol $^{(23)}$, HDL-c (High density lipoprotein cholesterol) (24) and LDL-c (Low density lipoprotein cholesterol) ${ }^{(25)}$ : using the corresponding colorimetric method.

2- Estimation of fasting plasma insulin: blood was collected on EDTA only, then centrifuged immediately at $4^{\circ} \mathrm{C}$, and was frozen at $-80^{\circ} \mathrm{C}$ for estimation of fasting plasma insulin by the ELISA kit provided by BioSource, Nivelles, Belgium.

3- Estimation of plasma ghrelin: blood was collected in tubes containing EDTA and aprotinin (500 KIU/ml; Trasylol; Bayer Corp., Leverkusen, Germany), then centrifuged immediately at $4^{\circ} \mathrm{C}$, and was frozen at $-80^{\circ} \mathrm{C}$ till time of assay. Plasma ghrelin levels were measured using an enzyme linked immunoassay (ELISA) kit provided by Phoenix Pharmaceuticals, Belmont, CA, USA.

4- Estimation of plasma resistin: blood was collected on EDTA only, then centrifuged immediately at $4^{\circ} \mathrm{C}$, and was frozen at $-80^{\circ} \mathrm{C}$ for estimation of plasma resistin using enzyme linked immunosorbent assay (ELISA) kit provided by BioVendor Laboratory Medicine, Inc., Brno, Czech Republic.

5- Insulin sensitivity: was estimated using the homeostatic assessment model for insulin resistance
$\left(\mathrm{HOMA}_{\mathrm{IR}}\right)$ with the formula: fasting plasma glucose $(\mathrm{mmol} / \mathrm{l}) \mathrm{x}$ fasting plasma insulin $(\mu \mathrm{IU} / \mathrm{ml}) /$ $22.5^{(26)}$.

Fat composition:

All dual-energy X-ray absorptiometry (DEXA) measurements for assessment of fat composition were done on Lunar Prodigy, GE medical system, USA. Total fat and lean tissues were calculated in kilograms, percentages of truncal body fat were, also, assessed, and this was done in reference to matched age, weight (according to BMI) and sex.

\section{Statistical Methods:}

The results were analyzed using Statistical Package for Social Science (SPSS) program version 10.0 (Chicago-IL, USA) ${ }^{(27)}$. Data were presented as mean \pm S.D. Student ttest was used for analysis of two quantitative data. Differences among the three groups were compared by one-way ANOVA followed by posthoc test. Simple linear correlation (Pearson's correlation for quantitative data and Spearman correlation for qualitative data) was done to detect the relation between the ghrelin and resistin with all other demographic and laboratory data. Stepwise multiple regression analysis was done for detection of independent determining factors affecting ghrelin and resistin. The results were considered statistically significant at $\mathrm{p}<0.05$.

\section{RESULTS}

The main clinical and anthropometric characteristics (mean \pm SD) in hemodialysis, pre-dialysis and control subjects are shown in 
table (1). There was no significant difference between groups regarding age, sex, systolic and diastolic blood pressure, BMI, truncal fat mass, and body fat mass. However, patients on hemodialysis had significantly lower mean values $(\mathrm{p}<0.05)$ of lean body mass compared to pre-dialysis patients and control groups, while the difference was insignificant between the pre-dialysis and the control groups.

Table 1: Clinical characteristics and anthropometric measurements in hemodialysis, pre-dialysis and control groups

\begin{tabular}{|c|c|c|c|c|}
\hline Variables & $\begin{array}{c}\text { Hemodialysis } \\
\text { Group I } \\
\text { n= } \mathbf{3 0}\end{array}$ & $\begin{array}{c}\text { Pre-dialysis } \\
\text { Group II } \\
\text { n=30 } \\
\end{array}$ & $\begin{array}{c}\text { Control } \\
\text { Group III } \\
\mathbf{n}=\mathbf{2 0} \\
\end{array}$ & p-value \\
\hline Age (years) & $42.4 \pm 13.1$ & $43.3 \pm 13.02$ & $43.2 \pm 12.3$ & 0.9 \\
\hline $\operatorname{Sex}(F / M)$ & $15 / 15$ & $14 / 16$ & $10 / 10$ & 0.9 \\
\hline Systolic BP (mmHg) & $125.4 \pm 9.9$ & $122.7 \pm 10.4$ & $120.7 \pm 6.7$ & 0.2 \\
\hline Diastolic BP (mmHg) & $79.7 \pm 11.3$ & $78 \pm 5.9$ & $77 \pm 6.4$ & 0.6 \\
\hline BMI $\left(\mathrm{Kg} / \mathrm{m}^{2}\right)$ & $27.3 \pm 5.6$ & $27.9 \pm 5.3$ & $28.2 \pm 4.8$ & 0.8 \\
\hline Truncal fat mass $(\%)$ & $31.4 \pm 10.45$ & $32.1 \pm 9.9$ & $34.4 \pm 9.6$ & 0.5 \\
\hline Body fat mass (kg) & $32.6 \pm 11.1$ & $32.1 \pm 9.3$ & $31.7 \pm 8.5$ & 0.9 \\
\hline Lean body mass (kg) & $38.9 \pm 7.6^{\mathrm{a}}$ & $44.3 \pm 11.4^{\mathrm{b}}$ & $45.5 \pm 6.2^{b}$ & $<0.05^{*}$ \\
\hline \multicolumn{3}{|c|}{$\begin{array}{l}\text { Values are expressed as means } \pm S . D \\
P \text {-value is significant if }<0.05^{*}\end{array}$} & \multicolumn{2}{|c|}{$\begin{aligned} B P & =\text { Blood pressure } \\
B M I & =\text { Body mass index }\end{aligned}$} \\
\hline
\end{tabular}

Different symbols indicate significant difference

The biochemical studied results (mean $\pm \mathrm{SD}$ ) of diseased and control subjects are shown in table (2). The mean creatinine and fasting plasma glucose levels were significantly higher in hemodialysis than the other two groups, and also, significantly higher in pre-dialysis patients compared to control subjects.

Lipid profile showed that there was no significant difference between groups regarding mean values of cholesterol and LDL-c. However, patients on hemodialysis had significantly higher levels of triacylglycerols compared to the predialysis and control groups, but, there was no significant difference between the two latter groups as regards triacylglycerols. On the other hand, the hemodialysis group exhibited significantly lower levels of HDL-c compared to both pre-dialysis and control groups, but, there was no significant difference between the predialysis and control groups as regard HDL-c. The fasting insulin level was significantly higher in both hemodialysis and pre-dialysis groups compared to controls, and, no significant difference was observed between the two groups.

The mean values of plasma ghrelin and resistin were significantly higher $(p<0.001)$ in patients with hemodialysis when compared to both pre-dialysis and control subjects. Furthermore, mean plasma ghrelin and resistin levels were significantly higher $(\mathrm{p}<0.001)$ in pre-dialysis patients compared to control subjects (table 2) (figures1\& 2). 
Table 2: Biochemical results of hemodialysis, pre-dialysis and control groups

\begin{tabular}{|l|l|l|l|l|}
\hline \multicolumn{1}{|c|}{ Variables } & $\begin{array}{c}\text { Hemodialysis } \\
\text { Group I } \\
\text { n= 30 }\end{array}$ & $\begin{array}{c}\text { Pre-dialysis } \\
\text { Group II } \\
\text { n=30 }\end{array}$ & $\begin{array}{c}\text { Control } \\
\text { Group III } \\
\text { n= 20 }\end{array}$ & p-value \\
\hline Creatinine $(\mathrm{mg} / \mathrm{dl})$ & $10.1 \pm 2.7^{\mathrm{a}}$ & $4.11 \pm 0.77^{\mathrm{b}}$ & $0.89 \pm 0.1^{\mathrm{c}}$ & $<0.001^{*}$ \\
\hline F.Glucose $(\mathrm{mg} / \mathrm{dl})$ & $\left.105.2 \pm 9.04^{\mathrm{a}}\right)$ & $98.9 \pm 14.0^{\mathrm{b}}$ & $91.3 \pm 11.4^{\mathrm{c}}$ & $<0.01^{*}$ \\
\hline Total cholesterol $(\mathrm{mg} / \mathrm{dl})$ & $182.1 \pm 27.7$ & $191.6 \pm 20.5$ & $191.4 \pm 19.5$ & 0.3 \\
\hline Triacylglycerol $(\mathrm{mg} / \mathrm{dl})$ & $139.9 \pm 50.8^{\mathrm{a}}$ & $117.1 \pm 23^{\mathrm{b}}$ & $114.1 \pm 27.6^{\mathrm{b}}$ & $<0.05^{*}$ \\
\hline HDL-c $(\mathrm{mg} / \mathrm{dl})$ & $42.1 \pm 4.3^{\mathrm{a}}$ & $47.9 \pm 6.3^{\mathrm{b}}$ & $49.1 \pm 6.3^{\mathrm{b}}$ & $<0.001^{*}$ \\
\hline LDL-c $(\mathrm{mg} / \mathrm{dl})$ & $115.2 \pm 20.3$ & $119.1 \pm 19$ & $120.6 \pm 17.5$ & 0.6 \\
\hline Insulin $(\mu \mathrm{IU} / \mathrm{ml})$ & $9.5 \pm 2.4^{\mathrm{a}}$ & $8.86 \pm 2.9^{\mathrm{a}}$ & $7.5 \pm 2.1^{\mathrm{b}}$ & $<0.05^{*}$ \\
\hline HOMA $\mathrm{IR}_{\mathrm{F}}$ & $2.3 \pm 0.83^{\mathrm{a}}$ & $2.27 \pm 0.5^{\mathrm{a}}$ & $1.7 \pm 0.5^{\mathrm{b}}$ & $<0.01^{*}$ \\
\hline Ghrelin $(\mathrm{ng} / \mathrm{ml})$ & $10.8 \pm 3.7^{\mathrm{a}}$ & $5.1 \pm 1.6^{\mathrm{b}}$ & $2.57 \pm 1^{\mathrm{c}}$ & $<0.001^{*}$ \\
\hline Resistin $(\mathrm{ng} / \mathrm{ml})$ & $12.7 \pm 2.6^{\mathrm{a}}$ & $5.6 \pm 0.98^{\mathrm{b}}$ & $4.7 \pm 0.9^{\mathrm{c}}$ & $<0.001^{*}$ \\
\hline
\end{tabular}

Values are expressed as means \pm S.D $\quad$ F. Glucose $=$ Fasting plasma glucose

$P$-value is significant if $<0.05 * \quad$ Different symbols indicate significant difference

$H O M A_{I R}=$ Homeostasis model assessment of insulin resistance

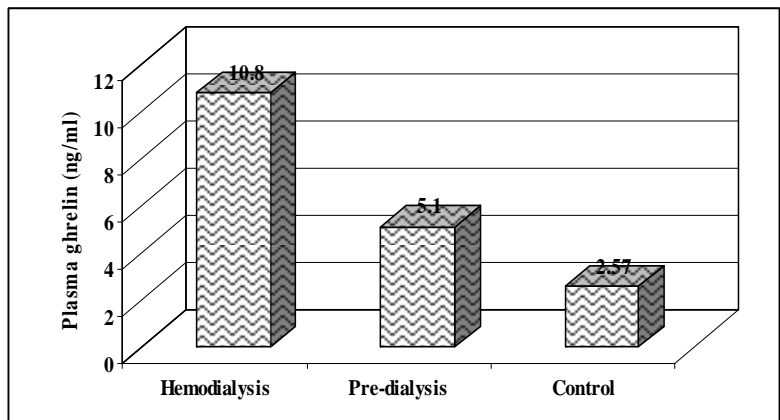

Fig.1: Mean plasma ghrelin levels in hemodialysis, pre-dialysis and control groups

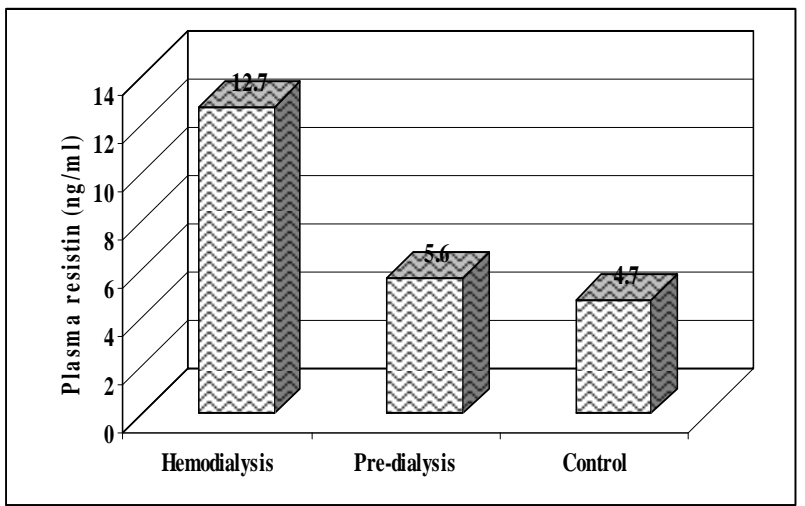

Fig.2: Mean plasma resistin levels in hemodialysis, pre-dialysis and control groups 
In hemodialysis group, the plasma ghrelin levels were inversely correlated significantly with plasma resistin $(\mathrm{r}=-0.41, \mathrm{p}<0.05)$ (figure 3), BMI $(\mathrm{r}=-0.85, \mathrm{p}<0.001)$, insulin $(\mathrm{r}=0.5, \mathrm{p}<0.01), \mathrm{HOMA}_{\mathrm{IR}}(\mathrm{r}=0.49$, $\mathrm{p}<0.01)$, and truncal fat mass $(\mathrm{r}=$ $0.4, \mathrm{p}<0.05$ ) (figure 4). While, it was positively correlated significantly with creatinine $(\mathrm{r}=0.7, \mathrm{p}<0.001)$. By using stepwise multiple regression analysis in hemodialysis group, plasma ghrelin was shown to be dependent on the BMI $(\mathrm{p}<0.001)$ only.

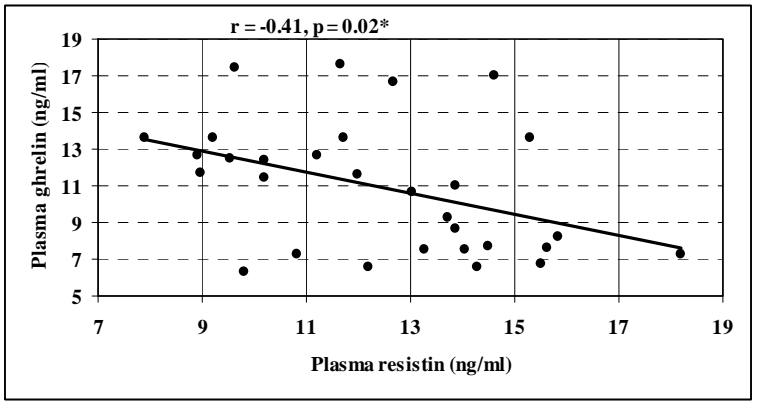

Fig.3: Correlation between plasma ghrelin and plasma resistin in hemodialysis group $(r=-0.41, p<0.05)$

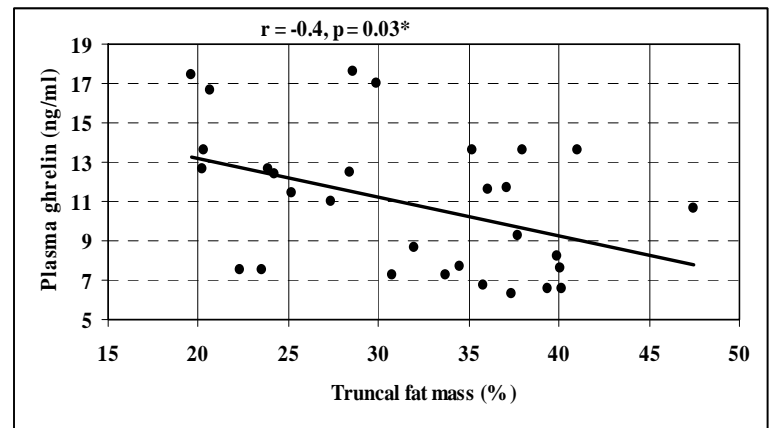

Fig. 4: Correlation between plasma ghrelin and truncal fat mass in hemodialysis $\operatorname{group}(r=-0.4, p<0.05)$

In pre-dialysis patients, there was significant negative correlation between plasma ghrelin and BMI $(\mathrm{r}=$ $-0.35, \mathrm{p}<0.05)$, plasma insulin $(\mathrm{r}=-$ $0.37, \mathrm{p}<0.05), \mathrm{HOMA}_{\mathrm{IR}}(\mathrm{r}=-0.3, \mathrm{p}<$ $0.05)$, and truncal fat mass $(\mathrm{r}=-0.37$, $\mathrm{p}<0.05)$. While, there was significant positive correlation between plasma ghrelin and creatinine $(\mathrm{r}=0.39, \mathrm{p}<$
$0.01)$, and lean body mass $(\mathrm{r}=0.58, \mathrm{p}$ $<0.001$ ) (figure 5). As regards the plasma resistin level in pre-dialysis group, no significant correlation was observed with any of the studied parameters. By using stepwise multiple regression analysis in this group, plasma ghrelin was shown to be dependent on BMI only $(\mathrm{p}<0.05)$. 


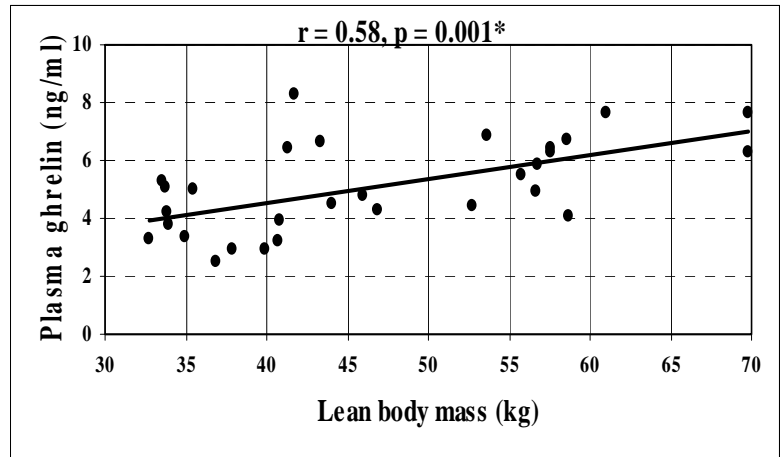

Fig. 5: Correlation between plasma ghrelin and lean body mass in pre-dialysis group $(r=0.58, p<0.001)$

In control subjects, plasma ghrelin was inversely correlated significantly with BMI $(\mathrm{r}=-0.45, \mathrm{p}<$ $0.05)$, truncal fat mass $(\mathrm{r}=-0.66, \mathrm{p}<$ $0.001)$, and body fat mass $(\mathrm{r}=-0.63, \mathrm{p}$ $<0.01$ ), but, positively correlated significantly with creatinine $(\mathrm{r}=0.47$, $\mathrm{p}<0.05$ ). While, plasma resistin level in controls showed significant negative correlation with truncal fat mass $(r=-0.45, p<0.05)$, and body fat mass $(r=-0.44, p<0.05)$, but, significant positive correlation with lean body mass $(\mathrm{r}=0.52, \mathrm{p}<0.05)$. By using stepwise multiple regression analysis, plasma ghrelin was shown to be dependent on truncal fat mass $(\mathrm{p}<$ 0.001).

\section{DISCUSSION}

Anorexia and malnutrition are common in end-stage renal failure (ESRF), they could be due to many causes, which may include uremia per se, as well as various co-morbidities and psychosocial factors. Anorexia and malnutrition are important predictors of prognosis ${ }^{(\mathbf{2 8})}$. The aim of the present study was to measure the serum levels of ghrelin and resistin in chronic renal failure and to evaluate their interrelationship, as well as their correlations with insulin resistance and body fat composition.

The present study demonstrated that plasma ghrelin levels were significantly higher in hemodialysis patients compared to the pre-dialysis group and control subjects. This could be attributed to decreased clearance and/or degradation of ghrelin by the failing kidney ${ }^{(29)}$. The increased plasma ghrelin concentration may rather represent a physiological adaptation to a long-term negative energy balance associated with wasting in ESRF patients ${ }^{(30)}$. Wynne et al. $^{(31)}$ reported that subcutaneous ghrelin administration might improve short-term food intake in dialysis patients with mild-to-moderate malnutrition. Indeed, Masaoka et al. ${ }^{\text {(32) }}$ demonstrated in streptozotocininduced diabetes in rats that a negative energy balance may enhance ghrelin secretion into the blood stream. 
Plasma ghrelin was positively correlated significantly with serum creatinine in hemodailysis patients and even in patients with mild to severe renal impairment (pre-dialysis group). Similar results were obtained by Lglesias et al. ${ }^{(33)}$.

In the present study, plasma ghrelin was negatively correlated significantly with BMI and truncal fat mass, these results were in agreement with the study of Ayala et al. ${ }^{(30)}$ who investigated patients with ESRF and found significantly higher plasma ghrelin concentrations in hemodialysis group, and its level correlated negatively with body mass index, and truncal fat mass. Moreover, the association between plasma ghrelin and body composition in ESRF is indirectly supported by significant inverse correlations between ghrelin and plasma insulin and $\mathrm{HOMA}_{\mathrm{IR}}$. Indeed, findings by Saad et al. ${ }^{(34)}$ indicated that insulin is a physiological and dynamic modulator of plasma ghrelin. On the other hand, another study demonstrated that a reduction in ghrelin is only seen at supraphysiological insulin concentrations (35). A relationship between ghrelin and adipose tissue has been reported. Ghrelin stimulates adipogenesis, and circulating ghrelin levels are reduced in obesity ${ }^{(\mathbf{1 4})}$. Malnutrition associated with uraemia is characterized by loss of lean body mass with preservation of fat mass leading to absolute or relative fat excess. It has been hypothesized that this altered pattern of body composition could be the result of a direct effect of the adipogenic and lipogenic effects of hyperghrelinaemia in these patients ${ }^{(36)}$.
As regards resistin, its plasma concentration was significantly increased in non-diabetic patients with ESRF treated with hemodialysis compared to both pre-dialysis and control groups. This finding confirms the results of a cross-sectional study by Diez et al. $^{(37)}$ in which elevated resistin levels were observed in patients with ESRF in comparison to the levels in patients with chronic renal failure on conservative management (pre-dialysis patients) and to reference values. Necla et al. $^{(38)}$ also, reported that serum resistin levels were increased in the children with chronic renal impairment; however, this elevation was not found to be associated with hyperinsulinism. Resistin levels were found to be increased already in early stages of renal insufficiency and to rise progressively parallel with the impairment of renal function ${ }^{(39)}$. Nüsken et al. ${ }^{(\mathbf{4 0})}$ reported that resistin concentrations were significantly elevated in hemodialysis and CRF pediatric subjects compared to healthy controls, and found that hemodialysis did not eliminate resistin. On the basis of the present findings, it is anticipated that increased resistin levels in renal failure are due to reduced renal resistin filtration or renal resistin catabolism, which is in parallel with declining glomerular filtration rate ${ }^{(41)}$. Resistin as a small molecule (25 KDa) should pass unrestricted through the glomerular membrane. Therefore, glomerular filtration with subsequent tubular catabolism is probably involved in the elimination of resistin ${ }^{(42)}$.

The putative association between resistin and insulin resistance has 
attracted a lot of interest ${ }^{(10,16,43)}$. However, in humans, existing data is more controversial than in rodents. Relationships of murine resistin expression with obesity and insulin resistance cannot be translated to humans. The exact physiological role of resistin is unknown ${ }^{(44,45)}$. In the present study, no correlation between fasting plasma resistin levels and insulin resistance $\left(\mathrm{HOMA}_{\mathrm{IR}}\right)$ was demonstrated in any of the studied groups. The current results confirm those of Filippidis et al. ${ }^{(46)}$ who found no significant correlation between serum resistin levels and $\mathrm{HOMA}_{\mathrm{IR}}$ or insulin and glucose levels in hemodialysis patients, and also, in agreement of the study of Kielstein et al. ${ }^{(39)}$ who found no relationship between plasma levels of resistin and markers of glucose metabolism, despite markedly elevated resistin levels in chronic kidney disease patients with IgA nephropathy.

Although fat mass is likely an important source of resistin and several proinflammatory cytokines ${ }^{(47)}$, no significant relationship between truncal or body fat mass and resistin levels were observed in hemodialysis or pre-dialysis patients in the current study. This is in accordance with the result of Axelsson et al. ${ }^{\left({ }^{(2)}\right.}$ who found no significant correlation between resistin and fat mass, and contrary to what has been reported in non-renal patients $^{\mathbf{( 4 8 , 4 9 )}}$. In this regard, resistin appears to differ from ghrelin, which is related to fat mass. Nüsken et al. ${ }^{(40)}$ also, reported that the suggested hypothesis that elevated serum resistin in children with chronic renal failure or ESRF may add to malnutrition and reduced BMI needs further investigation and was not supported by their data.

However, the negative correlation between plasma resistin and both truncal and body fat mass and its positive correlation with lean body mass in control group was supported by previous studies ${ }^{(\mathbf{4 8 , 4 9 )}}$. This observation is of interest because in experimental studies, resistin was found to be secreted mainly by adipocytes. These indirect observations at least question the role of body fat as a major secretory organ for resistin and the development of insulin resistance in renal patients.

An interesting finding in the present study showed that plasma ghrelin was negatively correlated with plasma resistin in the hemodialysis group only. This observation concurred with the findings of Asakawa et al. ${ }^{(50)}$ who found that the administration of ghrelin reduced resistin mRNA expression in white adipose tissue.

In conclusion, Plasma ghrelin and resistin concentration were markedly elevated in patients with ESRF, which might be caused by decreased metabolism or excretion during renal failure. The inversed relationship observed between ghrelin and body fat suggests that the role of ghrelin elevation in ESRF patients may be most probably a compensatory pathway rather than a causative factor and may raise the possibility that ghrelin replacement therapy may alleviate some of the clinical symptoms of anorexia in uremic patients. Lack of association between the increased plasma resistin and fat composition and insulin resistance suggest that resistin is not likely a 
mediator of nutritional status and insulin resistance in ESRF patients.

\section{REFERENCES}

1. Mehrotra $\mathbf{R}$ and Kopple JD. (2001): Nutritional management of maintenance dialysis patients: Why aren't we doing better? Annu. Rev. Nutr., 21: 343-379.

2. Kopple JD. (1999): Therapeutic approaches to malnutrition in chronic dialysis patients: The different modalities of nutritional support. Am. J. Kid. Dis., 33: 180-185.

3. Kopple JD, Zhu $X$, Lew NL, Lowrie EG. (1999): Body weight-forheight relationships predict mortality in maintenance hemodialysis patients. Kid. Int., 56: 1136-1148.

4. Kojima M, Hosoda $H$, Date $Y$, Nakazato $M$, Matsuo $H$, Kangawa K. (1999): Ghrelin is a growth-hormone-releasing acylated peptide from stomach. Nature 402:656-60.

5. Steppan CM, Bailey ST, Bhat S, Brown EJ, Banerjee RR, Wright CM, Patel HR, Ahima RS, Lazar MA. (2001): The hormone resistin links obesity to diabetes. Nature 409:307-312.

6. Yoshihira F, Kojima $M$, Hosoda $H$, Nakazato $M$, Kangawa K. (2002): Ghrelin: a novel peptide for growth hormone release and feeding regulation. Curr. Opin. Nutr. Metab. Care 5: 391-395.

7. Mori K, Yoshimoto A, Takaya K. (2000): Kidney produces a novel acylated peptide, ghrelin. FEBS (Lett.) 486: 213-216.
8. Eisenstein $\mathbf{J}$ and Greenberg $\mathbf{A}$. (2003): Ghrelin: update 2003. Nutr. Rev. 61: 101-104.

9. Nakazato $\mathbf{M}$, Murakami $\mathbf{N}$, Date Y. (2001): A role for ghrelin in the central regulation of feeding. Nature 409: 194-198.

10. Wren AM, Seal LJ, Cohen MA. (2001): Ghrelin enhances appetite and increases food intake in humans. J. Clin. Endocrinol. Metab., 86: 5992-5995.

11. Wisse BE, Frayo RS, Schwartz MW, Cummings DE. (2001): Reversal of cancer anorexia by blockade of central melanocortin receptors in rats. Endocrinology 14: 3292-3301.

12. Nagaya N, Uematsu M, Kojima M. (2001): Elevated circulating levels of ghrelin in cachexia associated with chronic heart failure: relationships between ghrelin and anabolic/catabolic factors. Circulation 104: 20342038.

13. Otto B, Cuntz U, Fruehauf E. (2001): Weight gain decreases elevated plasma ghrelin concentrations of patients with anorexia nervosa. Eur. J. Endocrinol., 145: 669-673.

14. Tschop M, Weyer C, Tataranni PA, Devanarayan V, Ravussin E, Heiman ML. (2001): Circulating ghrelin levels are decreased in human obesity. Diabetes 50: 707-709.

15. Steppen CM and Lazar MA. (2002): Resistin and obesityassociated insulin resistance. Trends. Endocrinol. Metab., 13: 18-23.

16. Alvestrand A. (1997): Carbohydrate and insulin 
metabolism in renal failure.

Kidney Int., 52: S48-S52.

17. Fliser D, Pacini G, Engelleiter R. (1998): Insulin resistance and hyperinsulinaemia are present already in patients with incipient renal disease. Kidney Int., 53: 1243-1247.

18. Kato Y, Hayashi M, Ohno Y, Suzawa T, Sasaki T, Saruta T. (2000): Mild renal dysfunction is associated with insulin resistance in chronic glomerulonephritis. Clin. Nephrol., 54: 366-373.

19. World health organization. (1998): Obesity: preventing and managing the global epidemic. Geneva.

20. Heinegard $D$ and Tiderstrom. (1973): Determination of serum creatinine by direct colorimetric method. Clin. Chim. Acta 43:305310 .

21. Trinder L. (1969): Determination of blood glucose using an oxidase-peroxidase system with a non- carcinogenic chromagen. Ann. Clin. Biochem., 6: 24-29.

22. Fossati $P$ and Prencipe $L$. (1982): Determination of triglycerides colorimetrically with an enzyme that produces hydrogen peroxide. Clin. Chem., 28: 2077-2080.

23. Kayamori $\mathbf{Y}$, Hatsuyama $\mathbf{H}$, Tsujioka T, Nasu M, Katayama Y. (1999): Endpoint colorimetric method for assaying total cholesterol with cholesterol dehydrogenase. Clin. Chem., 45: 2158-2163.

24. Finley PR, Schifman RB, Williams RJ, Lichti DA. (1978): Cholesterol in high-density lipoprotein: use of $\mathrm{Mg} 2+$ dextran sulfate in its enzymic measurement. Clin. Chem., 24: 931-933.

25. Friedewald WT, Levy RI, Fredrickson DS. (1972): Estimation of low density cholesterol in plasma without use of the preparative ultracentrifugation. Clin. Chem., 18:499-502.

26. Matthews DR, Hosker JP, Rudenski AS, Naylor BA, Treacher DF, Turner RC. (1985): Homeostasis model assessment: insulin resistance and beta-cell function from fasting plasma glucose and insulin concentrations in man. Diabetologia 28: 412-419.

27. Norusis M J. (1997): SPSS 7.5 guide to data analysis, Simon and Schuster Company, Upper Saddle River. New Jersey.

28. Havel PJ. (2001): Peripheral signals conveying metabolic information to the brain: shortterm and long-term regulation of food intake and energy homeostasis. Exp. Biol. Med., 226: 963-977.

29. Jarkovska Z, Rosicka M, Krsek M, Sulkova S, Haluzik M. (2005): Plasma Ghrelin Levels in Patients with End-Stage Renal Disease. Physiol. Res., 54: 403408.

30. Ayala ER, Pecoits-Filho $R$, Heimburger $O$, Lindholm B, Nordfors L, Stenvinkel P. (2004): Associations between plasma ghrelin levels and body composition in end-stage renal disease: A longitudinal study. Nephrol. Dial. Transplant., 19: 421-426. 
31. Wynne K, Giannitsopoulou K, Small CJ, Patterson M, Frost G, Ghatei MA, Brown EA, Bloom SR, Choi P. (2005): Subcutaneous ghrelin enhances acute food intake in malnourished patients who receive maintenance peritoneal dialysis: a randomized, placebo-controlled trial. J. Am. Soc. Nephrol., 6: 2111-2118.

32. Masaoka T, Suzuki H, Hosoda H. (2003): Enhanced plasma ghrelin levels in rats with streptozotocin-induced diabetes. FEBS (Lett.) 541: 64-68.

33. Lglesias P, Diez JJ, Reyest F, Codoceo R, Fidalgo A, Bajo MA, Aguilera A, Selgas D. (2006): Serum ghrelin concentrations in patients with chronic renal failure undergoing dialysis. Clin. Endocrinol., 69: 68-73.

34. Saad MF, Bernaba B, Hwu CM. (2002): Insulin regulates ghrelin concentrations. J. Clin. Endocrinol. Metab., 87: 39974000.

35. Schaller G, Schmidt A, Pleiner J, Woloszczuk W, Wolzt $M$, Luger A. (2003): Plasma ghrelin concentrations are not regulated by glucose or insulin: a doubleblind, placebo-controlled crossover clamp study. Diabetes 52: 16-20.

36. Barazzoni R, Zanetti M, Biolo G, Guarnieri G. (2005): Metabolic effects of ghrelin and its potential implications in uremia. J. Ren. Nutr., 15: 111115.

37. Diez JJ, Iglesias P, FernandezReyes MJ, Aguilera A, Bajo MA, Alvarez-Fidalgo $P$,
Codoceo R, Selgas R. (2005):

Serum concentrations of leptin, adiponectin and resistin, and their relationship with cardiovascular disease in patients with end-stage renal disease. Clin. Endocrinol., 62: 242-249.

38. Necla B; Aysun B, Ozan O, Erol O, Sevcan B, Sevim G, Harun P, Oguz S, Peyami C. (2006): Leptin and resistin levels and their relationships with glucose metabolism in children with chronic renal insufficiency and undergoing dialysis. Nephrology 11: 192-196.

39. Kielstein JT, Becker B, Graf S, Brabant G, Haller H, Fliser D. (2003): Increased resistin blood levels are not associated with insulin resistance in patients with renal disease. Am. J. Kid. Dis., 42: 62-66.

40. Nüsken KD, Kratzsch J, Wienholz V, Stöhr W, Wolfgang W, Dötsch J. (2006): Circulating resistin concentrations in children depend on renal function. Nephrology Dialysis Transplantation 21:107112.

41. Moestrup SK and Nielsen LB. (2005): The role of the kidney in lipid metabolism. Current Opinion in Lipidology 16: 301306.

42. Axelsson J, Bergsten A, Qureshi AR, Heimbürger $O$, Bàràny $P$, Lönnqvist $F$, Lindholm B, Nordfors L, Alvestrand A, Stenvinkel $P$. (2006): Elevated resistin levels in chronic kidney disease are associated with decreased glomerular filtration rate and 
inflammation, but not with insulin resistance. Kidney Int., 69: 596604.

43. Banerjee RR, Rangwala SM, Shapiro JS. (2004): Regulation of fasted blood glucose by resistin. Science 303: 1195-1198.

44. Heilbronn LK, Rood J, Janderova L, Albu JB, Kelley DE, Ravussin E, Smith SR. (2004): Relationship between serum resistin concentrations and insulin resistance in non-obese, obese, and obese diabetic subjects. J. Clin. Endocrinol. Metab., 89: 1844-1848.

45. Pfutzner A, Langenfeld $M$, Kunt T. (2003): Evaluation of human resistin assays with serum from patients with type 2 diabetes and different degrees of insulin resistance. Clin. Lab., 49: 571576.

46. Fillipidis G, Liakopoulos V, Mertens PR, Kiopoulos T, Stakias N, Verikouki C, Patsidis E, Koukoulis G, Stefanidis I. (2005): Resistin serum levels are increased but not correlated with insulin resistance in chronic hemodialysis patients. Blood puri., 23: 421-428.

47. Axelsson J, Rashid Qureshi A, Suliman ME. (2004): Truncal fat mass as a contributor to inflammation in end-stage renal disease. Am. J. Clin. Nutr., 80: 1222-1229.

48. Valsamakis G, McTernan PG, Chetty R. (2004): Modest weight loss and reduction in waist circumference after medical treatment are associated with favorable changes in serum adipocytokines. Metabolism 53: 430-434.

49. Azuma K, Katsukawa F, Oguchi S. (2003): Correlation between serum resistin level and adiposity in obese individuals. Obes. Res., 11: 997-1001.

50. Asakawa A, Inui A, Kaga $T$, Katsuura G, Fujimiya M, Fujino MA, Kasuga M. (2003): Antagonism of ghrelin receptor reduces food intake and body weight gain in mice. Gut 52: 947952. 


\title{
إرتباط الجرلين والريسيستين بتركيب دهون الجسم ومقاومة الإسولين في مرضى الفشل الكلوي المزمن
}

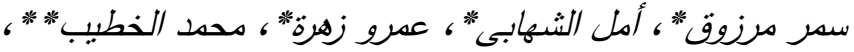

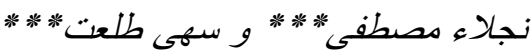 \\ أقسام الكيمياء الحيوية الطبية *- الأمراض الباطنة **** الأثعة التشخيصية \\ كلية الطب- جامعة القاهرة
}

إن الهرمونات التي تنظم الطاقة متل الجرلين والأديبوسيتوكين منل الريسيستين قد تلعب دورا في الفشل

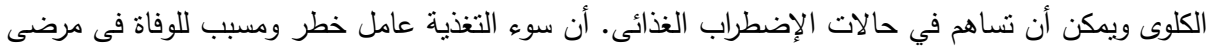

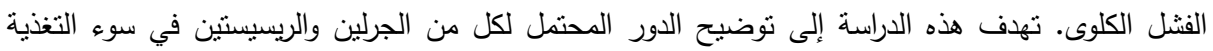

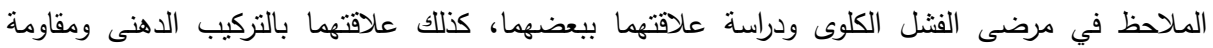

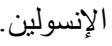

اشتملت الدراسة على • ج مريضاً و • شخصاً كمجوعة ضابطة ممانلة فى العمر والجنس ومعامل كتلة

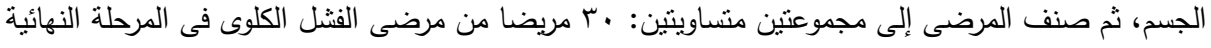

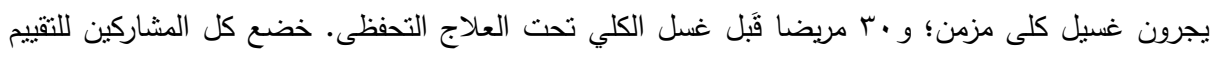
الإكلينيكى الثامل، وقياس مستويات الدهون ومستويات السكر والكرياتنينين والإنسولين الصائم و الجرلين والريسيستين فى البلازما. تم حساب مقاومة الإنسولين باستعمال نموذج النقييم الطبيعى لمقاومة الإنسولين وقياس تركيب الجسم في كل المشاركين بواسطة مقياس الامتصاص بالأثنعة السينية ثنائية الطاقة.

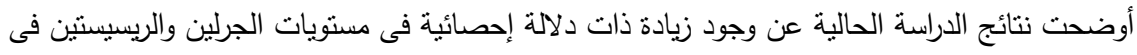

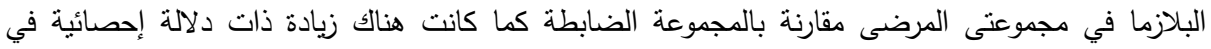

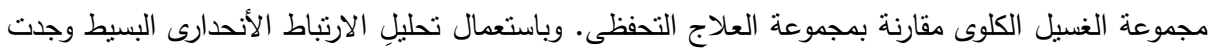

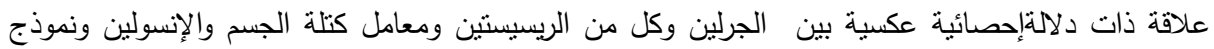
التقييم الطبيعى لمقاومة الإنسولين وكتلة الدهون الخصرية، لكن وجدت علإقالة ذاتل دات دلالة إحصائية إيجابية

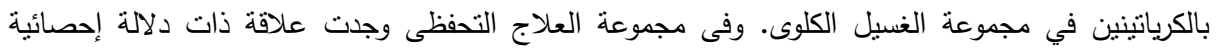
عكسية بين الجرلين و معامل كتلة الجسم والإنسولين ونموذج التقييم الطبيعى لمقاومة الإنسولين وكتلة الدهون الخصرية، لكن وجدت علاقة ذات دلالة إحصائية إيجابية بالكرياتينين وكتلة الجسم الخالية من الدهون. أما لإنائ

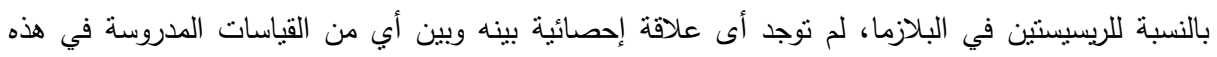

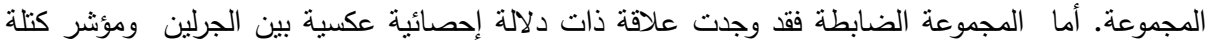
الجسم وكتلة الدهون الخصرية وكتلة الدهون الجسمية ووجود علاقة ذات دلالة إحصائية إيجابية بكتلة الجسم 
الخالية من الدهون. أما الريسيستين فقد وجدت علاقة ذات دلالة إحصائية عكسية بكتلة الدهون الخصرية وكتلة الدهون الجسمية و علاقة ذات دلالة إحصائية إيجابية بكتلة الجسم الخالية من الدهون. كَثف التهات التحليل الانحدارى المضاعف أن الجرلين يعتمد على معامل كتلة الجسم في مجموعتي الغسيل الكلوى والعلاج التحفظى، ويعتمد على كتلة الدهون الخصرية في المجموعة الضابطة. ويمكن أن يستخلص من هذه الدراسة أن إرتفاع نركيز الجرلين والريسيستين بدرجة كبيرة في المرحلة النهاية لمرضى الكلي، قد يرجع إلى سبب أيضى أو نقص الإفراز من الكلية أثناء الفشل الكلوي. والعلاقة

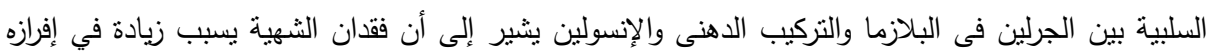

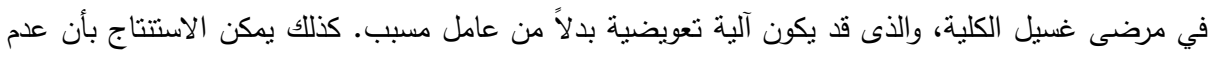
وجود علاقة بين الريسيسنين مع التركيب الدهنى ومقاومة الإنسولين يشير إلى أنه ليس وسيطاً محتملاً فى لئ

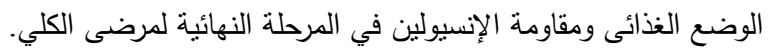

